\title{
The relation between serum vitamin D levels and clinical findings of fibromyalgia syndrome
}

\author{
Serum vitamin D seviyelerinin fibromiyalji sendromunun klinik bulgulart ile ilişkisi
}

\author{
Nurcan Kılıç Baygutalp', Fatih Baygutalp², Buminhan Şeferoğlu², Ebubekir Bakan
}

\section{ABSTRACT}

Objective: This study was performed to identify serum $25-\mathrm{OH}$ vitamin $\mathrm{D}$ levels and to investigate the relationship between $25-\mathrm{OH}$ vitamin $\mathrm{D}$ and clinical findings on patients with fibromyalgia syndrome (FMS).

Methods: Nineteen premenopausal women with FMS who were diagnosed according to ACR 1990 fibromyalgia diagnostic criteria and 24 premenopausal healthy women as control group were included in the study. Serum $25-\mathrm{OH}$ vitamin $\mathrm{D}$ levels were determined in both patient and control groups. Widespread body pain, headache, fatigue, morning stiffness, sleep disorder, the number of tender points, Fibromyalgia Impact Questionnaire (FIQ) scores and Beck depression scores were evaluated as clinical findings in patients with FMS.

Results: Serum 25-OH vitamin D levels were significantly lower in patients with FMS than those in control group $(p=0.01)$. There were significantly negative correlations between $25-\mathrm{OH}$ vitamin $\mathrm{D}$ levels and widespread body pain ( $r=-0.731)$, Beck depression scores $(r=-0.777)$, headache $(r=-0.629)$, and sleep disorder $(r=-0.767)$ in the FMS group $(p<0.01)$.

Conclusion: It was concluded that $25-\mathrm{OH}$ vitamin $\mathrm{D}$ deficiency may be related to the clinical findings such as widespread body pain, depression, headache and sleep disorder in patients with FMS.

Key words: Fibromyalgia, clinical finding, $25-\mathrm{OH}$ vitamin D

\section{INTRODUCTION}

Fibromyalgia syndrome (FMS) is a chronic pain syndrome causing widespread body pain, stiffness, and tenderness points on specific anatomic regions. It is also characterized by restless sleep, tiredness,

\section{ÖZET}

Amaç: Bu çalışma, fibromiyalji sendromlu (FMS) hastalarda serum $25-\mathrm{OH}$ vitamin $\mathrm{D}$ seviyelerini belirlemek ve $25-\mathrm{OH}$ vitamin D seviyelerinin klinik bulgular ile ilişkisini araştırmak amacıyla yapııdı.

Yöntemler: Çalışmaya ACR 1990 fibromiyalji tanı kriterlerine göre tanı konulan ondokuz premenapozal kadın ve kontrol grubu olarak 24 premenapozal sağlıklı kadın dahil edildi. Yaygın vücut ağrısı, baş ağrısı, yorgunluk, sabah tutukluğu, uyku bozukluğu, hassas nokta sayısı, fibromiyalji etki anketi skorları ve Beck depresyon skorları FMS'nin klinik bulguları olarak değerlendirildi.

Bulgular: Serum 25-OH vitamin D seviyeleri FMS'li hastalarda kontrol grubuna göre anlamlı olarak daha düşüktü $(p=0.01)$. FMS grubunda $25-\mathrm{OH}$ vitamin $\mathrm{D}$ seviyeleri ile yaygın vücut ağrısı ( $r=-0.731)$, Beck depresyon skorları $(r=-0.777)$, baş ağrısı $(r=-0.629)$ ve uyku bozukluğu arasında $(r=-0.767)$ anlamlı negatif korelasyonlar vardı $(p<0.01)$

Sonuç: $25-\mathrm{OH}$ vitamin $\mathrm{D}$ eksikliğinin FMS'nin yaygın vücut ağrısı, depresyon, baş ağrısı ve uyku bozukluğu gibi klinik bulguları ile ilişkili olabileceği değerlendirildi.

Anahtar kelimeler: Fibromiyalji, klinik bulgu, 25-OH vitamin D

fatigue, anxiety, depression, and disturbances in bowel functions $[1,2]$.

The etiopathogenesis of fibromyalgia syndrome (FMS) remains unknown. The interactions of neuroendocrine, metabolic and immunological factors are assumed to play role in the induction and mainte-

${ }^{1}$ Ataturk University Faculty of Medicine, Department of Medical Biochemistry, Erzurum, Turkey

${ }^{2}$ Ataturk University Faculty of Medicine, Department of Physical Medicine and Rehabilitation, Erzurum, Turkey

Yazışma Adresi /Correspondence: Nurcan Kılıc Baygutalp,

Ataturk University Faculty of Medicine, Dept. Medical Biochemistry, Erzurum, Turkey Email: eczbaygutalp80@gmail.com

Geliş Tarihi / Received: 02.06.2014, Kabul Tarihi / Accepted: 14.07.2014

Copyright @ Dicle Tıp Dergisi 2014, Her hakkı saklıdır / All rights reserved 
nance of FMS [3,4]. Neuroendocrine mechanisms, various hormones, serotonin, melatonin, substance $\mathrm{P}$, endorphins, and vitamin D levels were researched on until now with respect to the etiopathogenesis of FMS [5-9].

The relationship between low levels of $25-\mathrm{OH}$ vitamin $\mathrm{D}$ and non-specific skeletal-muscular pains including FMS is controversial. While a positive correlation was found between vitamin D levels and FMS in many studies, no relationship was found in others.

The aim of this study is to determine serum 25$\mathrm{OH}$ vitamin D levels in patients with FMS and the control group of healthy individuals. Additionally, the correlations between 25-OH vitamin D levels and some of the clinical findings of FMS - widespread body pain, headache, fatigue, morning stiffness, sleep disorder, the number of tender points, Fibromyalgia Impact Questionnaire (FIQ) and Beck depression scores - were evaluated.

\section{METHODS}

Nineteen premenopausal women (aged 27-47 years, average $36.35 \pm 7.04$ years) who were admitted to our outpatient clinic between 1 July - 30 August 2011 and met the 1990 American College of Rheumatology (ACR) criteria for the diagnosis of FMS were enrolled in the study. The control group was composed of twenty-four age and location matched healthy premenopausal women who had normal physical examination and routine test results and had no chronic and endocrinological diseases. 25$\mathrm{OH}$ vitamin $\mathrm{D}$ levels were determined in FMS patients and controls.

Widespread body pain, headache, fatigue, morning stiffness, sleep disorder, the number of tender points, Fibromyalgia Impact Questionnaire (FIQ) and Beck depression scores were evaluated as clinical findings in patients. Fibromyalgia Impact Questionnaire (FIQ) was evaluated by Turkish version [10] of original FIQ [11]. The number of tender points was determined by ACR 1990 diagnostic criteria [12]. Depression scores were evaluated by Turkish version [13] of original Beck Depression Scale [14]. Widespread pain and fatigue were measured with $10-\mathrm{cm}$ visual analog (VAS) scale [15]. Morning stiffness was evaluated by morning stiff- ness scale of Lequesne index (as $0=$ no stiffness, $1=$ low stiffness-less than 15 minutes, $2=$ severe stiffness-more than 15 minutes) [16].

Sleep disorder was evaluated sleep latency component of Pittsburgh Sleep Quality Index (as $0=$ no difficulty or difficulty falling asleep for $\leq 15$ minutes, $1=$ difficulty falling asleep for 16-30 minutes, $2=$ difficulty falling asleep for 31-60 minutes, $3=$ difficulty falling asleep for more than $60 \mathrm{~min}$ utes) [17]. Headache was evaluated by 4 definitive words of Short-Form McGill Pain Questionnaire used to determine the affective dimensions of pain (as $0=$ no headache, $1=$ low headache, $2=$ mild headache, $3=$ severe headache) [18].

Since neuroendocrine abnormalities have role in FMS etiopathogenesis, premenopausal women were included into the study. All subjects were asked to complete a general questionnaire including questions about detailed personal medical history, vitamin $\mathrm{D}$ usage, age, location, menstruation cycle, smoking and alcohol consumption. Participants who had neurological, inflammatory, endocrine, chronic disease, osteoporosis, pregnancy previously existing psychiatric illness and taking vitamin D supplementation were excluded from the study. Since serum 25-OH vitamin D levels show seasonal variations and summer sunshine is an important source of vitamin D, blood samples were taken from the patients in July and August.

Serum 25-OH vitamin D levels were measured in Roche E170 hormone analyzer by electrochemiluminescence method and results were reported in units of $\mathrm{ng} / \mathrm{ml}$.

Descriptive statistical methods (mean, standard deviation) were used to evaluate the data. All results are expressed as mean plus minus standard deviation and percentage. The unpaired Student's t test was used to evaluate the significance of differences between groups. Spearman correlation analysis was used to determine the correlations between findings. $P$ values less than 0.05 were considered significant, at $95 \%$ confidence interval. Data were analyzed using the SPSS/PC statistical software package (SPSS, v.20.0 for Windows, SPSS Inc. Chicago).

This study was approved by the ethics committee of Ataturk University Faculty of Medicine, and informed consent was obtained from each subject. 
The procedures followed were in accordance with the ethical standards of the responsible committee on human experimentation and with the Helsinki Declaration of 1975, as revised in 1983.The authors declare that there is no conflict of interest.

\section{RESULTS}

The mean age of patients was $35 \pm 7.45$ years for the FMS group and $36 \pm 8.29$ years for the control group. There were no significant differences between groups in terms of age $(\mathrm{p}>0.05)$. The mean duration of symptoms in the FMS group was $4.35 \pm 1.20$ years. The mean tender point score in the FMS group was $15.3 \pm 1.8$ points.

25-OH vitamin D levels of FMS patients and control group are shown in Table 1. Serum $25-\mathrm{OH}$ vitamin D levels were significantly lower in patient group compared with control group $(p=0.04)$. There was no significant correlation between age and 25$\mathrm{OH}$ vitamin D levels. Mean, standard deviation and percentage values of clinical findings are given in Table 2.

The correlations of 25-OH vitamin D levels and clinical findings in FMS patients were analyzed (Table 3 ). There were significantly negative correlations between 25-OH vitamin D levels and widespread body pain $(\mathrm{r}=-0.731, \mathrm{p}<0.01)$, Beck depression scores $(-0.777, \mathrm{p}<0.01)$, headache $(-0.629$, $\mathrm{p}<0.01)$, and sleep disorder $(\mathrm{r}=-0.767, \mathrm{p}<0.01)$ in FMS patients.

Table 1. 25-OH vitamin D levels of FMS patients and the control group

\begin{tabular}{llll}
\hline & FMS group & Control group & $\mathbf{p}$ \\
\hline $\begin{array}{l}25-\mathrm{OH} \text { vitamin D } \\
(\mathrm{ng} / \mathrm{ml})\end{array}$ & $13.92 \pm 6.19$ & $20.49 \pm 7.63$ & 0.04 \\
\hline
\end{tabular}

Table 2. Mean, standard deviation and percentage values of clinical findings in FMS patients

\begin{tabular}{lll}
\hline Clinical finding & Mean \pm SD & $\%$ \\
\hline WBP & $3.97 \pm 2.65$ & \\
Fatique & $2.83 \pm 2.45$ & \\
FIQ & $19.27 \pm 21.52$ & \\
NTP & $5.95 \pm 5.45$ & \\
Beck DS & $23.46 \pm 21.22$ & \\
Morning Stiffness (minutes) & $12.36 \pm 4.74$ & \\
Headache & & 73.70 \\
Sleep Disorder & & 63.20 \\
\hline
\end{tabular}

SD: Standard deviation, WBP: Widespread Body Pain, FIQ: Fibromyalgia Impact Questionnaire, NTP: Number of Tender Points, Beck DS: Beck Depression Scores

Table 3. Correlation coefficients ( $r$ ) of $25-\mathrm{OH}$ vitamin $\mathrm{D}$ levels with clinical findings in FMS patients

\begin{tabular}{|c|c|c|c|c|c|c|c|c|}
\hline & WBP & Fatigue & FIQ & NTP & Beck DS & Morning Stiffness & Headache & Sleep Disorder \\
\hline 25-OH Vitamin D & $-0.731^{*}$ & 0.196 & 0.231 & -0.250 & $-0.777^{*}$ & 0.683 & $-0.629 *$ & $-0.767^{*}$ \\
\hline
\end{tabular}

WBP: Widespread Body Pain, FIQ: Fibromyalgia Impact Questionnaire, NTP: Number of Tender Points, Beck DS: Beck Depression Scores, ${ }^{*}: p<0.01$

\section{DISCUSSION}

The main aim of the study is to identify serum 25$\mathrm{OH}$ vitamin $\mathrm{D}$ levels and to investigate the relationship between $25-\mathrm{OH}$ vitamin $\mathrm{D}$ and clinical findings on patients with fibromyalgia syndrome (FMS), which is a chronic pain syndrome.

In literature, findings on vitamin $\mathrm{D}$ levels in FMS patients show varying scores. Many studies examining vitamin D levels in FMS patients in different countries of the world have reported low or insufficient levels. Low levels have been reported in studies which were conducted in Europe [19,20], the United States [21], in S. Arabia and Pakistan with a high percentage of as $74 \%$ of FMS patients [22]. Low levels of vitamin D were also reported in a recent study conducted on 141 FMS patients in Turkey. Vitamin D deficiency was detected in 76 $\%$ of patients and it was concluded that vitamin D treatment in FMS patients might cause regression of disease symptoms [23].

On the contrary there are studies which have not reported differences in serum levels of vitamin D levels between FMS patients and healthy controls [24]. Similar with most studies in the literature, in our study vitamin D levels in patients with FMS 
were found to be lower than the level in the control group.

The relation of vitamin D deficiency and chronic pain is also focused in literature. In many studies vitamin D deficiency is pointed to play a role in chronic widespread pain syndromes including fibromyalgia $[25,26]$. Although the basic function of vitamin $\mathrm{D}$ is to regulate bone metabolism, muscle and nervous system are two of the target organs of vitamin D [27].

Even though it is not exactly known how vitamin D deficiency creates pain and how vitamin D therapy reduces pain, there is strong evidence for abnormal central pain processing in FMS in vitamin $\mathrm{D}$ insufficiency. There are several theories on how vitamin D level affects pain. One of these theories suggests that insufficient vitamin D causes impairment on bone metabolism by a series of reactions. Insufficient vitamin D levels impair bone mineralization by causing formation of a spongy matrix below the periosteal membrane. This gelatin-like matrix can expand by liquid absorption and can cause formation of an outward pressure from periosteum. As a result, it causes pain generation in these tissues, which are highly innerved by nerve fibers $[28,29]$. Another theory suggests that infections activate inflammatory cytokines, which modulates central and peripheral pain sensation in FMS [30]. Since $1,25(\mathrm{OH}) 2$ vitamin $\mathrm{D}$ takes part in immune system regulation, a relationship can be set between vitamin D deficiency and muscle pains [31].

In a recent study conducted with a large population of 3495 women and 3365 men FMS patients, relationship between $25-\mathrm{OH}$ vitamin D levels and increased pain level in female patients were reported [31].

On the other hand, in many studies conducted with FMS patients, negative correlations were also found between vitamin D levels and widespread body pain [25], and skeletal pain [26]. In our study, negative correlations were found between vitamin $\mathrm{D}$ levels and widespread body pain and headache in FMS patients. Our results point additional evidence on the fact that vitamin D deficiency might create pain.

Since FMS patients have various symptoms and no significant disorder could be found by physical examination and laboratory findings, symptoms are thought to be psychological. Many studies showed negative correlation between 25-OH vitamin D levels and Beck depression scores on FMS patients $[32,33]$. Besides there are many reasons for abnormal pain sensation and other symptoms of FMS patients, psychological disorders are accepted to have a role in improvement of severity of pain sensation.

Another noteworthy finding of our study is, the significant negative correlation $(r=-0.777, p<0.01)$ found between vitamin D levels and Beck depression scores in FMS patients supports the data that increased prevalence of depression might be observed in FMS patients.

In a study determining $25-\mathrm{OH}$ vitamin $\mathrm{D}$ levels in FMS patients and healthy controls, much sleep disturbance was reported to be seen in patients who had lower 25-OH vitamin D levels [33]. Similarly, a relationship between $25-\mathrm{OH}$ vitamin $\mathrm{D}$ levels and sleep disturbance was found in our study.

As a result of our study, we determined that vitamin D levels are lower in patients with FMS than those in control group, and we concluded that vitamin D levels are effective on FMS symptoms. Since etiopathogenesis of FMS is not well known, treatment of FMS should be planned according to existence and severity of prominent symptoms.

Small sample size is the limitation of our study. Since determination and, if necessary, replacement of 25-OH vitamin D levels can play a key role in treatment of FMS symptoms; we consider that, relation between $25-\mathrm{OH}$ vitamin $\mathrm{D}$ and fibromyalgia symptoms should be supported by follow-up studies conducted in large number of patients, including study groups with and without vitamin D supplementation.

\section{REFERENCES}

1. Gupta A, Silman AJ. Psychological stress and fibromyalgia: a review of the evidence suggesting a neuroendocrine link. Arthritis Res Ther 2004;6:98-106.

2. Marder WD, Meenan RF, et al.The present and future adequacy or heumatologyman power. A study of health care needs and physician supply. Arthritis Rheum 1991;34:1209-1217.

3. Abeles AM, Pillinger MH, Solitar BM, Abeles M. Narrative review: the pathophysiology of fibromyalgia. Ann Intern Med 2007;146:726-734. 
4. Gur A. Etiopathogenesis in Fibromyalgia. Turk J Phys Med Rehab 2008;54:4-11.

5. Dessein PH, Shipton EA, Joffe BI, et al. Hyposecretion of adrenal androgens and the relation of serum adrenal steroids, serotonin and insulin-like growth factor-1 to clinical features in women with fibromyalgia. Pain 1999;83:313319.

6. Senel K, Baygutalp F, Baykal T, et al. Melatonin levels in premenopausal women with fibromyalgia syndrome. Rheumatol Int 2013;33:1609-1610.

7. Karatay S, Yıldırım K, Melikoglu MA, Senel K. The relationship of endocrine hormone levels and clinical parameters in the young patients with fibromyalgia. J PM\&R 2003;3:117-120.

8. Bhatty SA, Shaikh NA, Irfan M et al. Vitamin D deficiency in fibromyalgia. J Pak Med Assoc 2010;60:949-951.

9. KilicBaygutalp, Seferoglu B, Baygutalp F, Senel K. The correlation of serum prolactin levels and clinical parameters in the patients with fibromyalgia syndrome. J PMR Sci 2013;16:83-87.

10. Burckhardt CS, Clark SR, Bennett RM. The Fibromiyalgia Impact Questionnaire: developmentand validation. J Rheumatol 1991;18:728-733.

11. Sarmer S, Ergin S, Yavuzer G. The validity and reliability of the Turkish version of the Fibromyalgia Impact Questionnaire. Rheumatol Int 2000;20:9-12.

12. Wolfe F, Smythe HA, Yunus MB, et al. The American College of Rheumatology 1990 criteria for the classification of fibromyalgia Arthritis Rheum 1990;33:160-172.

13. Ulusoy M, Sahin N, Erkmen H. Turkish version of the Beck Anxiety Inventory. Psychometric properties. J Cognit Psychother1996;46:125-132.

14. Beck AT, Steer RA, Carbin MG. Psychometric properties of the Beck Depression Inventory: Twenty-five years of evaluation. Clin Psychol Rev 1988;8:77-100.

15. Chapman CR, Casey KL, Dubner R, et al. Pain measurement: an overview. Pain 1985;22:1-31.

16. Lequesne MG, Mery C, Samson M, Gerard P. Indexes of severity for osteoarthritis of the hip and knee. Scand J Rheumatol Suppl 1987;65:85-89.

17. Buysse DJ, Reynolds CF, Monk TH, et al. The Pittsburgh Sleep Quality Index: A new instrument for psychiatric practice and research. Psychiatry Res 1989:193-213.

18. Dworkin RH, Turk DC, Revicki DA, et al. Development and initial validation of an expanded and revised version of the Short-form McGill Pain Questionnaire (SF-MPQ-2) Pain 2009;144:35-42.
19. Nellen JF, Smulders YM, Jos Frissen PH, Slaats EH, Silberbusch J. Hypovitaminosis D in immigrant women: Slow to be diagnosed. BMJ 1996;312: 570-572.

20. Erkal MZ, Wilde J, Bilgin Y, et al. High prevalence of vitamin D deficiency, secondary hyperparathyroidism and generalized bone pain in Turkish immigrants in Germany: Identification of risk factors. Osteoporos Int 2006; 17:11331140 .

21. Plotnikoff GA, Quigley JM. Prevalence of severe hypovitaminosis D in patients with persistent, nonspecific musculoskeletal pain. Mayo Clin Proc 2003;78:1463-1470.

22. Badsha H, Daher M, Ooi Kong K. Myalgias or non-specific muscle pain in Arab or Indo-Pakistani patients may indicate vitamin D deficiency. Clin Rheumatol 2009;8:971-973.

23. Kose N. Blood vitamin D levels in patients with fibromyalgia and the effectiveness of vitamin D treatment. Dicle Med J 2013;40:585-588.

24. Tandater H, Grynbaum M, Zuili I, et al. Serum 25-OH vitamin D levels in patients with fibromyalgia. Isr Med Assoc J 2009; 11:339-342.

25. Abokrysha NT. Vitamin D deficiency in women with fibromyalgia in Saudi Arabia. Pain Med 2012;13:452-458.

26. Heidari B, Shirvani JS, Firouzjahi A, et al. Association between nonspecific skeletal pain and vitamin D deficiency. Int J Rheum Dis 2010;13:340-346.

27. Senel K, Baykal T. Vitamin D: Muscle Tissue and Fall. J Pediatr Sci 2012;8:143-147.

28. Shinchuk LM, Holick MF. Vitamin D and rehabilitation: Improving functional outcomes. Nutr Clin Pract 2007;22:297304.

29. Yew KS, DeMieri PJ. Disorder of bone mineral metabolism. Clin Fam Pract 2002;4:525-565.

30. Staud R. Fibromyalgia pain: do we know the source? Curr Opin Rheumatol 2004;16:157-163.

31. Atherton K, Berry DJ, Parsons T, Vitamin D and chronic widespread pain in a white middle-aged British population: Evidence from a cross-sectional population survey. Ann Rheum Dis 2009;68:817-822.

32. Armstrong DJ, Meenagh GK, Bickle I, Finch MB. Vitamin $\mathrm{D}$ deficiency is associated with anxiety and depression in fibromyalgia. Clin Rheumatol 2007;26:551-554.

33. Olama SM, Senna MK, Elarman MM, Elhawary G. Serum vitamin $\mathrm{D}$ level and bone mineral density in premenopausal Egyptian women with fibromyalgia. Rheumatol Int 2013;33:185-192. 